\title{
Feasibility study of organic matter and Ammonium removal using loofa sponge as a supporting medium in an aerated submerged fixed-film reactor (ASFFR)
}

\author{
Ramin Nabizadeh* ${ }^{\#}$ \\ Department of Environmental Health Engineering \\ School of Public Health, Medical Sciences \\ University of Tehran \\ P.O. BOX 14155-6446 \\ Tehran, Iran \\ Tel: 982188954914 \\ Fax: 982188950188 \\ E-mail: rnabizadeh@tums.ac.ir \\ Kazem Naddafi \\ Department of Environmental Health Engineering \\ School of Public Health, Medical Sciences \\ University of Tehran \\ P.O. BOX 14155-6446 \\ Tehran, Iran \\ Tel: 982188954914 \\ Fax: 982188950188 \\ E-mail: knaddafi@tums.ac.ir \\ Alireza Mesdaghinia \\ Department of Environmental Health Engineering \\ School of Public Health, Medical Sciences \\ University of Tehran \\ P.O. BOX 14155-6446 \\ Tehran, Iran \\ Tel: 982188954914 \\ Fax: 982188950188 \\ E-mail: amesdaghinia@tums.ac.ir \\ Amir Hosien Nafez \\ Department of Environmental Health Engineering \\ School of Public Health, Medical Sciences \\ University of Tehran \\ P.O. BOX 14155-6446 \\ Tehran, Iran \\ Tel: 982188954914 \\ Fax: 982188950188 \\ E-mail: nafez_amir@yahoo.com
}

Financial support: This research was supported by Tehran University of Medical Sciences and Health Services grant No 132/11852 Dated 19-3-2006.

Keywords: aerated submerged fixed-film reactor, biofilm, Fixed-Film, loofa, organic matter removal, sponge.

Present address: "Department of Environmental Health Engineering, School of Public Health, Tehran University of Medical Sciences, Poursina St. Tehran, Iran. Tel: 9821 88954914, Fax: 982166462267.

Abbreviations: ASFFR: aerated submerged fixed-film reactor

BOD: biochemical oxygen demand

COD: chemical oxygen demand

SCOD: soluble chemical oxygen demand

TKN: total Kjeldahl Nitrogen

TP: total phenols

Biofilm systems are efficient in the removal of organic

loofa sponge, a natural product, was used as a matter and ammonium from wastewaters. In this study,

*Corresponding author 
reactor to evaluate its performance in removing organic matter and nitrogen from wastewater. Four pilot runs were performed with chemical oxygen demand (COD) concentrations of 100, 200, 300 and $400 \mathrm{mg} \mathrm{l}^{-1}$ to provide an organic loading rate of $0.6,1.2,1.8$, and $2.4 \mathrm{~kg} \mathrm{~m}^{-3} \mathrm{~d}^{-1}$ respectively. In these pilot runs, the influent ammonium nitrogen concentrations were justified to $5,10,15$ and $20 \mathrm{mg} \mathrm{l}^{-1}$ as $\mathbf{N}$ to provide an influent nitrogen loading of $30,60,90$ and $120 \mathrm{~g} \mathrm{~m}^{-3} . \mathrm{d}^{-1}$ respectively. Although soluble COD removal efficiency greater than 80 percent was achieved up to a loading rate of $2.4 \mathrm{~kg} \mathrm{~m}^{-3} \mathrm{~d}^{-1}$, loofa deformation and clogging after 72 days of application might be considered a serious shortcoming during use in full-scale applications. Nitrogen removal efficiency decreased from $85.6 \%$ at an organic loading rate of 0.6 $\mathrm{kg} \mathrm{m}^{-3} \mathrm{~d}^{-1}$ to $56.1 \%$ at an organic loading rate of $2.4 \mathrm{~kg}$ $\mathbf{m}^{-3} \mathbf{d}^{-1}$.

It is generally accepted that biofilm systems which are technically categorized as attached growth systems, can be efficient in the removal of carbonaceous material from aqueous solutions such as wastewaters. A pilot plant study on petrochemical wastewater treatment with an aerated submerged fixed-film reactor (ASFFR) proved that $96 \%$ of organic removal at high loading rates could be achieved (Park et al. 1996). It has been shown that the ASFFR process is able to handle continuous high organic loads increasing from 5 to $120 \mathrm{~g} \mathrm{BOD} \mathrm{m}^{-2} \mathrm{~d}^{-1}$ with a slight decrease in organic removal efficiency from $97.9 \%$ to $88.5 \%$ for BOD and from $73.6 \%$ to $67.8 \%$ for COD (Hamoda and Al-Sharekh, 1999). The performance of the ASFFR under simultaneous organic and ammonium loading and its effect on nitrification has also been studied where organic loading varied between 1.93-5.29 $\mathrm{g} \mathrm{COD} \mathrm{m}^{-2}$ $\mathrm{d}^{-1}$ and $\mathrm{NH}_{4}-\mathrm{N}$ loadings were between 116-318 $\mathrm{mg} \mathrm{NH}_{4}-\mathrm{N}$ $\mathrm{m}^{-2} \mathrm{~d}^{-1}$. Results of this study showed that with organic loading rates up to $3.97 \mathrm{~g}$ COD m $\mathrm{m}^{-2}$, complete nitrification was achievable (Nabizadeh and Mesdaghinia, 2006). Biological nitrogen and phenol removal from saline industrial wastewater by submerged fixed-film reactor was also studied and showed the removal of total nitrogen as high as 83\% (Ramos et al. 2007). For nitrogen applied loads around $0.064 \mathrm{~kg} \mathrm{TKN} \mathrm{m}^{-3} \mathrm{~d}^{-1}$, the removal efficiency was reported as high as $95 \%$ which decreased to $84 \%$ for $0.14 \mathrm{~kg} \mathrm{TKN} \mathrm{m}^{3} \mathrm{~d}^{-1}$ (Delpozo and Diez, 2003).

It should be mentioned that the supporting medium which provides the required surface area for microbial growth, is considered to be the most important part of any attached growth system. Selection of support medium for a fixedfilm system is always considered as a critical step. In a single experiment, transparent plastic tube materials were tested to determine which material would be best as a support medium in a fixed-film bioreactor and the ability of green sulphur bacteria to grow on different transparent plastic tube materials was investigated (Henshaw at al. 1999). Designers of such systems always try to use supporting media which provide a large surface area for microorganisms to allow substrate removal. Since the emergence of ASFFR systems, the use of economical, efficient and durable media has always been a challenge. Different types of media of varying shape have been used to maximize the performance of the system. So far the application of sand, gravel, plastic either in cylindrical form or engineered design, stones, and artificial sponge have proved popular as packing in ASFFR systems. Pumice stones have also been used as a packing medium to study the performance of a toluene-degrading biofilm (Di Lorenzo et al. 2005). Adsorbent removal of methylene blue dye from aqueous solutions was investigated and average methylene blue adsorption capacity was determined as 49 mg g-1 (Demir et al. 2008). Recently, horizontal flow biofilm reactor with step-feed was used to remove organic carbon and nitrogen from agricultural strength synthetic wash water in which polystyrene horizontal sheets were used as microbial growth media (Rodgers et al. 2008). Higher COD removal efficiency in ASFFR could be achieved by optimization of media. For example, the application of polyester-urethane sponges (coarse sponge with higher density $\mathrm{S}_{28-30} / 45 \mathrm{R}$ and fine sponge with lower density $\left.\mathrm{S}_{16-18} / 80 \mathrm{R}\right)$ with sponge volume fraction of $10 \%$, indicated that the addition of sponge could increase COD removal efficiency (Ngo et al. 2008).

Some researchers tried to develop simple techniques for the entrapment of microorganisms. A novel immobilization technique was developed by using a structural fibrous network of papaya wood for immobilization of fungal hyphae (Iqbal and Saeed, 2005). Recently scientists have used natural products such as loofa (Luffa cylindrica) as a supporting medium. In 2004, alginate coated loofa sponge was used for the removal of cadmium from aqueous solutions in a continuous flow fixed-bed column bioreactor (Iqbal and Edyvean, 2004). Iqbal et al. (2005) studied the production of fungal biomass immobilized on loofa sponge for the removal of heavy metal ions and chlorinated compounds from aqueous solution. In another study, removal of phenolic compounds in olive oil mill wastewater using loofa-immobilized Phanerochaete chrysosporium was successfully carried out and the extent of removal of total phenols (TP) and COD was reported to be $90 \%$ and $50 \%$, respectively (Ahmadi et al. 2006). Recently, treatment of gaseous emissions contaminated with H2S by biofilters inoculated with single cultures of sulfur oxidizer bacteria was experienced (Aroca et al. 2007). But, there is still much tendency to use mixed culture in full-scale bioreactor.

Loofa is derived from the cucumber and marrow family and originates from America. After drying, the fibrous interior structure of the loofa changes into a $30 \mathrm{~cm}$ long sponge. The two main species which are grown throughout the world are the angled loofa ( $L$. acutangula), and the smoothfruited species (L. cylindrica, or L. aegyptica). Although the fruits can be eaten, it is most commonly grown for the fibrous internal material, which can be used as a sponge after being dried. As mentioned in the literature, the fibers are composed of $60 \%$ cellulose, $30 \%$ hemicellulose, and 
Table 1. Operating conditions at each run.

\begin{tabular}{|c|c|c|c|c|c|}
\hline $\begin{array}{l}\text { Pilot } \\
\text { Run }\end{array}$ & $\begin{array}{l}\text { Influent COD } \\
\left(\mathrm{mg} \mathrm{L}^{-1}\right)\end{array}$ & $\begin{array}{c}\text { Organic } \\
\text { loading rate } \\
\left(\mathrm{kg} \mathrm{COD}^{3} \mathrm{~d}^{-1}\right)\end{array}$ & $\begin{array}{l}\text { Air flow } \\
\left(\mathrm{L} \mathrm{min}^{-1}\right)\end{array}$ & $\begin{array}{l}\text { Influent Ammonium- } N \\
\left(\mathrm{mg} \mathrm{L}^{-1}\right)\end{array}$ & $\begin{array}{l}\text { Ammonium } \\
\text { loading rate } \\
\left(\mathrm{g} \mathrm{N} \mathrm{m}^{3} \mathrm{~d}^{-1}\right)\end{array}$ \\
\hline 1 & 100 & 0.6 & 5 & 5 & 30 \\
\hline 2 & 200 & 1.2 & 10 & 10 & 60 \\
\hline 3 & 300 & 1.8 & 15 & 15 & 90 \\
\hline 4 & 400 & 2.4 & 20 & 20 & 120 \\
\hline
\end{tabular}

$10 \%$ lignin and can be used in industry for many purposes, such as packaging, insulating, or as filling materials (Mazali and Alves, 2005).

Factors such as high surface area per volume, strong and durable structure, low specific gravity (which makes it light), and reasonable cost are characteristic of loofa making it a suitable alternative for use as a packing medium in an attached growth system. In this study, loofa sponge was used as a supporting medium in an ASFFR to evaluate its performance in removing organic matter and nitrogen from wastewater.

\section{MATERIALS AND METHODS}

\section{Preparation of loofa cylinders}

The loofa sponges were first cut at both ends and the seeds were taken out. Any resins and other impurities were removed from the peeled and dried loofa sponges by washing with water and detergent for $30 \mathrm{~min}$. The average length and weight of loofa cylinders were estimated to be $36.25 \mathrm{~cm}$ and $15.43 \mathrm{~g}$, respectively. Then, the loofa cylinders were cut longitudinally to ease sewage flow. Three longitudinal cuts were made in each loofa sponge. To prevent decay, loofa sponges were coated with a layer of lacquer. The lacquer solution was prepared using $100 \mathrm{~g}$ of solid lacquer which was added to $5 \mathrm{ml}$ of methanol and placed on a shaker for 4 hrs. Following preparation of the lacquer solution, the loofa sponges were submerged in the lacquer solution for $5 \mathrm{~min}$ and left to dry. This method was repeated 10 times to ensure that all surfaces of the sponges were completely covered by the lacquer. The lacquered sponges were then placed in the oven for $24 \mathrm{hrs}$ in $105^{\circ} \mathrm{C}$ which evaporated the alcohol and stabilized the lacquer on the loofa sponges.

As schematically shown in Figure 1, eight of the sponges were used in a pilot-run and were placed in two sections four on the top of the reactor and four on the bottom- where each loofa on the top was attached to the one underneath using wire to keep it in place. The weight of the 8 loofa sponges in the reactor was $123.42 \mathrm{~g}$ with a bulk density of $15.27 \mathrm{~kg} \mathrm{~m}^{-3}$.

\section{Pilot settings}

The ASFFR and other equipment used in the pilot system are shown in Figure 2. The effective volume of the reactor was approximately 8 liters in which the 8 loofa sponge cylinders were submerged. The void ratio of the reactor was calculated to be $90.32 \%$.

Air and synthetic wastewater were injected at the bottom of the reactor to maintain an up-flow current of liquid. An air compressor was used to supply the air required for the reactor. The air pipe was equipped with a filter to remove dust and other impurities. The air flow rate was simply determined using a flow meter which was adjusted using an adjusting valve to maintain the dissolved oxygen at the appropriate level. To avoid flow variation during the study, an equalization tank was used in the suction line of the pump. The equalization tank was connected to the wastewater storage tank through a floater. The floater opened and closed the valve and maintained a constant static head in the suction line.

\section{Start up and loading strategy}

After packing the reactor with the prepared loofa sponge cylinders, 5 liters of sludge from the returned sludge line of an activated sludge system were added to the reactor to provide the initial microbial mass. Then, 3 liters of synthetic wastewater was added to the reactor. Tap water was used during the preparation of the synthetic wastewater. Glucose as a carbon source, ammonium chloride $\left(\mathrm{NH}_{4} \mathrm{Cl}\right)$ as a nitrogen source and ammonium phosphate as a phosphorus source were added to the tap water to maintain a BOD:N:P ratio of 100:5:1. To avoid sharp $\mathrm{pH}$ changes in the reactor, alkalinity of the reactor contents was increased using sodium bicarbonate. Soluble COD and ammonium nitrogen were analyzed according to the procedures no. 5220-C and 4500-B, respectively (American Public Health Association, 2005). 
The reactor was operated in batch for 6 days and the amount of aeration adjusted to $5 \mathrm{l} \mathrm{min}^{-1}$ to maintain aerobic conditions. Glucose and other nutrients were added daily to ensure a soluble COD concentration of $500 \mathrm{mg} \mathrm{l}^{-1}$. After 6 days, the hydraulic regime of the reactor was changed to continuous and the hydraulic retention time (HRT) was adjusted to $4 \mathrm{hrs}$, in addition, at this stage, which was considered the first run, the concentration of influent COD was $100 \mathrm{mg} \mathrm{l}^{-1}$. After the complete establishment of biomass on the packed loofa medium and achievement of steady state conditions of the soluble COD concentration of the pilot plant effluent, the data of 10 consecutive days were analyzed to calculate average values. It should be also noted that the filter were not washed between each run.

The flow of the incoming wastewater was constant and organic loading rates were changed by increasing the substrate concentration. Four pilot runs were performed

Table 2. Statistical analysis of obtained results.

\begin{tabular}{|c|c|c|c|c|c|}
\hline \multirow{2}{*}{\multicolumn{2}{|c|}{ Statistical Parameters }} & \multicolumn{4}{|c|}{ Effluent Soluble COD (mg/L) } \\
\hline & & Run 1 & Run 2 & Run 3 & Run 4 \\
\hline \multicolumn{2}{|l|}{ Mean } & 17.8 & 13.2 & 31.4 & 74.8 \\
\hline \multirow{2}{*}{$\begin{array}{l}95 \% \text { Confidence } \\
\text { Interval for Mean }\end{array}$} & Lower Bound & 13.3 & 9.7 & 28.8 & 59.1 \\
\hline & Upper Bound & 22.3 & 16.7 & 34.0 & 90.5 \\
\hline \multicolumn{2}{|l|}{ Median } & 16.0 & 14.0 & 30.5 & 79.5 \\
\hline \multicolumn{2}{|l|}{ Variance } & 39.1 & 23.3 & 12.9 & 482.0 \\
\hline \multicolumn{2}{|l|}{ Std. Deviation } & 6.3 & 4.8 & 3.6 & 22.0 \\
\hline \multicolumn{2}{|l|}{ Minimum } & 11.0 & 7.0 & 28.0 & 45.0 \\
\hline \multicolumn{2}{|l|}{ Maximum } & 32.0 & 21.0 & 39.0 & 114.0 \\
\hline \multirow{2}{*}{\multicolumn{2}{|c|}{ Statistical Parameters }} & \multicolumn{4}{|c|}{ Effluent Ammonium-N (mg/L) } \\
\hline & & Run 1 & Run 2 & Run 3 & Run 4 \\
\hline \multicolumn{2}{|l|}{ Mean } & 0.72 & 1.47 & 6.61 & 8.80 \\
\hline \multirow{2}{*}{$\begin{array}{l}95 \% \text { Confidence } \\
\text { Interval for Mean }\end{array}$} & Lower Bound & 0.64 & 1.26 & 6.34 & 8.56 \\
\hline & Upper Bound & 0.80 & 1.67 & 6.87 & 9.04 \\
\hline \multicolumn{2}{|l|}{ Median } & 0.73 & 1.40 & 6.55 & 8.72 \\
\hline \multicolumn{2}{|l|}{ Variance } & 0.01 & 0.04 & 0.06 & 0.05 \\
\hline \multicolumn{2}{|l|}{ Std. Deviation } & 0.07 & 0.20 & 0.25 & 0.23 \\
\hline \multicolumn{2}{|l|}{ Minimum } & 0.63 & 1.30 & 6.30 & 8.60 \\
\hline \multicolumn{2}{|l|}{ Maximum } & 0.80 & 1.80 & 7.00 & 9.20 \\
\hline
\end{tabular}


with COD concentrations of 100, 200, 300 and $400 \mathrm{mg} \mathrm{l}^{-1}$ to provide organic loading rates of $0.6,1.2,1.8$, and $2.4 \mathrm{~kg}$ $\mathrm{m}^{-3} \mathrm{~d}^{-1}$ respectively. The loading rate was increased until clogging was observed. In the pilot runs, the influent ammonium nitrogen concentrations were justified to 5,10 , 15 and $20 \mathrm{mg} \mathrm{l}^{-1}$ as $\mathrm{N}$ to provide influent nitrogen loading of 30, 60, 90 and $120 \mathrm{~g} \mathrm{~m}^{-3} \cdot \mathrm{d}^{-1}$ respectively. The aeration flow rate which is presented in Table 1 was increased in proportion to the applied organic load to avoid causing oxygen limitation. During each pilot run, the reactor was continuously fed and effluent soluble COD was monitored.

\section{RESULTS AND DISCUSSION}

The results of applying different organic loading rates in this study are shown in Figure 3. As illustrated in Figure 3, after the start-up period and following a change in the flow regime from batch to continuous, the effluent soluble COD decreased rapidly and reached steady state conditions after 9 days. The average effluent soluble COD during this run was estimated to be $17.8 \mathrm{mg} \mathrm{l}^{-1}$. Figure 3 also shows the performance of the system when the COD concentration was changed to $200 \mathrm{mg} \mathrm{l}^{-1}$. As shown, the new steady state condition was reached after 6 days without any critical changes in effluent soluble COD due to the quick shift in COD concentration. The average effluent soluble COD during the second run was estimated to be $13.2 \mathrm{mg} \mathrm{l}^{-1}$ which showed a COD removal efficiency of $93.4 \%$. During the third run, the influent COD was changed to $300 \mathrm{mg} \mathrm{l}^{-1}$; the system tolerated this shock loading and after 10 days a new steady state was achieved. The average effluent soluble COD in the third run was estimated to be $31.4 \mathrm{mg} \mathrm{l}^{-}$ ${ }^{1}$ which represented a reduction in COD of $89.5 \%$. In the fourth run, the influent COD was increased to $400 \mathrm{mg} \mathrm{l}^{-1}$. As shown in Figure 3, the effluent soluble CODdecreased after this sharp increase which was due to the sudden load change and was seen up to 11 days after the application of this loading rate. However, unlike previous loadings, the effluent soluble COD increased sharply and did not remain steady which indicated clogging of the loofa medium. At this stage the wastewater was drained from the reactor. The variations in effluent soluble COD removal efficiency versus organic loading rates are presented in Figure 4. The COD removal efficiency in this work was between $81.3 \%$ and 93.4. In an experiment, the COD removal efficiency of ASFFR reactor reported from $67.5 \%$ to $73.6 \%$ (Hamoda and Al-Sharekh, 1999). With the specific surface area of SARAN 1000D of $400 \mathrm{~m}^{2} \mathrm{~m}^{-3}$ approximately, the soluble chemical oxygen demand removal efficiency of the reactor was demonstrated 91.8-96.6\% at organic loadings of 1.02$6.21 \mathrm{~kg} \mathrm{COD} \mathrm{m}^{-3} \mathrm{~d}^{-1}$ (Park et al. 1996). In another ASFFR system which was based on crude oil wastewater and was packed with Bee-Cell 2000 as support media having porosity of $87 \%$ and a specific surface area of $650 \mathrm{~m}^{2} \mathrm{~m}^{-3}$, system was able to achieve 83.14-97.05 percentage removal efficiencies of soluble chemical oxygen demand in the organic loading rate range of 0.84 to $9.41 \mathrm{~g}$ soluble chemical oxygen demand (SCOD) $\mathrm{m}^{-2} \mathrm{~d}^{-1}$ (Izanloo et al. 2006). It should be noted that the removal efficiency of
ASFFR reactor is related to many factors such as substrate biodegradability, total surface area of supporting media and operating conditions which make comparison difficult. But, the high COD removal efficiency of ASFFR in this work indicated that loofa sponge is appropriate enough to compete to the other alternative media in this respect.

Figure 5 indicates the effluent ammonium nitrogen concentrations during the first run in steady state conditions. The average concentration of effluent nitrogen was approximately $0.7 \mathrm{mg} \mathrm{l}^{-1}$. The average value of nitrogen removal efficiency of the system in the first pilot run was about $85.6 \%$. As illustrated in Figure 5, the system effectively tolerated the change in loading rate as in the second run the average concentration of effluent ammonium nitrogen was about $1.3 \mathrm{mg} \mathrm{l}^{-1}$ and the average value of ammonium removal efficiency of the system was calculated to be $87.3 \%$. As indicated, the concentration of effluent ammonium nitrogen increased considerably and average ammonium removal efficiency of the system declined to $65.7 \%$ in the third run. In the fourth pilot run, after a quick increase in effluent ammonium concentration due to the change in the organic loading rate, the system reached steady state conditions with an average ammonium removal of $56.1 \%$. After clogging of the loofa medium, the effluent ammonium nitrogen sharply increased after 78 days of the pilot run as indicated in Figure 5. These experiments showed that increasing the organic load to the reactor severely reduced the ammonium removal efficiency of the reactor. The statistical analysis of obtained data are briefly presented in Table 2 .

At the higher loading rates, the loofa sponges was deformed and clogged and the fiber structure was destroyed in many parts. The thickness of biofilm would be increased due to higher organic loading rates and it can provide the anaerobic condition in the inner layer of microbial film. In this condition the affinity of anaerobic bacteria to use the carbon of loofa might be increased which tends to the deterioration of media. Although alginate coated loofa sponges were used for the removal of cadmium from aqueous solutions in a continuous flow fixed-bed column bioreactor (Iqbal and Edyvean, 2004), according to the findings of the present study, loofa can not be classed as a long lasting medium since the sponges will decay after a period of time. Further research is necessary to stabilize this medium for use in biological reactors. It should be noted that in previous studies, the time periods involved were not long enough to observe decay of the sponges. For example, in the study by Iqbal and Edyvean (2004) the maximum time of exposure was 240 min which may not be enough time for deformation and decay of loofa sponges to take place. As previously noted, phenolic compounds were successfully removed from olive oil mill wastewater using loofa-immobilized $P$. chrysosporium, and the extent of removal of TP and COD were reported to be $90 \%$ and $50 \%$, respectively (Ahmadi et al. 2006). However, this study did not review the changes in the loofa medium in the long 
term which could affect the performance of the system in full-scale applications.

In conclusion, the use of loofa sponge as a supporting medium in an ASFFR showed satisfactory soluble COD removal up to a loading rate of $2.4 \mathrm{~kg} \mathrm{~m}^{-3} \mathrm{~d}^{-1}$. However, deformation and clogging of loofa at loading rates above this value may be considered a serious shortcoming of the use of loofa sponge in full-scale applications. Therefore, more research is required to find methods to stabilize loofa sponges to reduce or prevent decay during this bioprocess; otherwise the use of this natural product may be restricted to temporary use in overloaded suspended growth systems to enhance performance by increasing available cell mass.

\section{REFERENCES}

AHMADI, M.; VAHABZADEH, F.; BONAKDARPOUR, B.; MEHRAMINIAN, M. and MOFARRAH, E. Phenolic removal in olive oil mill wastewater using loofahimmobilized Phanerochaete chrysosporium. World Journal of Microbiology and Biotechnology, February 2006, vol. 22, no. 2, p. 119-127.

American Public Health Association. Standard methods for the examination of water and wastewater, $21^{\text {st }}$ ed. APHA/AWWA/WEF Washington DC. 2005.

AROCA, G.; URRUTIA, H.; NUNEZ, D.; OYARZUN, P.; ARANCIBIA, A. and GUERRERO, K. Comparison on the removal of hydrogen sulfide in biotrickling filters inoculated with Thiobacillus thioparus and Acidithiobacillus thiooxidans. Electronic Journal of Biotechnology, October 2007, vol. 10, no. 4, p. 514-520.

DELPOZO, R. and DIEZ, V. Organic matter removal in combined anaerobic-aerobic fixed-film bioreactors. Water Research, September 2003, vol. 37, no. 15, p. 3561-3568.

DEMIR, H.; TOP, A.; BALKOSE, D. and ULKU, S. Dye adsorption behavior of Luffa cylindrica fibers. Journal of Hazardous Material, May 2008, vol. 153, no. 1-2, p. 389394.

DI LORENZO, A.; VARCAMONT, M.; PARASCANDOLA, P.; BERNARDI, A.; SUCCEDDU, P.; SISTO, A. and ALTERIIS, E. Characterization and performance of a toluene-degrading biofilm developed on pumice stones. Microbial Cell Factories, January 2005, vol. 4, no. 4.

HAMODA, M.F. and AL-SHAREKH, H.A. Sugar wastewater treatment with aerated fixed-film systems. Water Science and Technology, 1999, vol. 40, no. 1, p. 313321.

HENSHAW, P.; MEDLAR, D. and MCEWEN, J. Selection of a support medium for a fixed-film green sulphur bacteria reactor. Water Research, 1999, vol. 33, no. 14, p. 31073110.
IQBAL, M. and EDYVEAN, R.G.J. Alginate coated loofa sponge discs for the removal of cadmium from aqueous solutions. Biotechnology Letters, January 2004, vol. 26, no. 2, p. 165-169.

IQBAL, M. and SAEED, A. Novel method for cell immobilization and its application for production of organic acid. Letters in Applied Microbiology, January 2005, vol. 40, no. 3, p. 178-182.

IQBAL, M.; SAEED, A.; EDYVEAN, R.G.J.; O'SULLIVAN, B. and STYRING, P. Production of fungal biomass immobilized loofa sponge (FBILS)-discs for the removal of heavy metal ions and chlorinated compounds from aqueous solution. Biotechnology Letters, September 2005, vol. 27 , no. 17 , p. $1319-1323$.

IZANLO, H.; MESDAGHINIA A.; NABIZADEH, R.; NASSERI,S.; NADDAFI, K.; MAHVI, A.H. and NAZMARA, S.H. Effect of organic loading on the performance of aerated submerged fixed-film reactor (ASFFR) for crude oil-containing wastewater treatment. Iranian Journal of Environmental Health Science and Engineering, March 2006, vol. 3, no. 2, p. 85-90.

MAZALI I.O. and ALVES, O.L. Morphosynthesis: high fidelity inorganic replica of the fibrous network of loofa sponge (Luffa cylindrica). Anais da Academia Brasileira de Ciências, 2005, vol. 77, no. 1, p. 25-31.

NABIZADEH, R. and MESDAGHINIA, A. Behavior of an Aerated Submerged Fixed-Film Reactor (ASFFR) under simultaneous organic and ammonium loading. Journal of Environmental Quality, April 2006, vol. 35, no. 3, p. 742748.

NGO, H.; GUO, W. and XING, W. Evaluation of a novel sponge-submerged membrane bioreactor (SSMBR) for sustainable water reclamation. Bioresource Technology, May 2008, vol. 99, no. 7, p. 2429-2435.

PARK, T.J.; LEE, H.K.; KIM, S.D. and KIM, W.C. Petrochemical wastewater treatment with Aerated Submerged Fixed-Film Reactors (ASFFR) under high organic loading. Water Science and Technology, 1996, vol. 34, no. 10, p. 9-16.

RAMOS, A.F.; GOMEZ, M.A.; HONTORIA, E. and GONZALEZ-LOPEZ, J. Biological nitrogen and phenol removal from saline industrial wastewater by submerged fixed-film reactor. Journal of Hazardous Materials, April 2007, vol. 142, no. 1-2, p. 175-183.

RODGERS, M.; De PAOR, D. and CLIFFORD E. Dairy washwater treatment using a horizontal flow biofilm system. Journal of Environmental Management, January 2008, vol. 86, no. 1, p. 114-120. 


\section{APPENDIX}

\section{FIGURES}

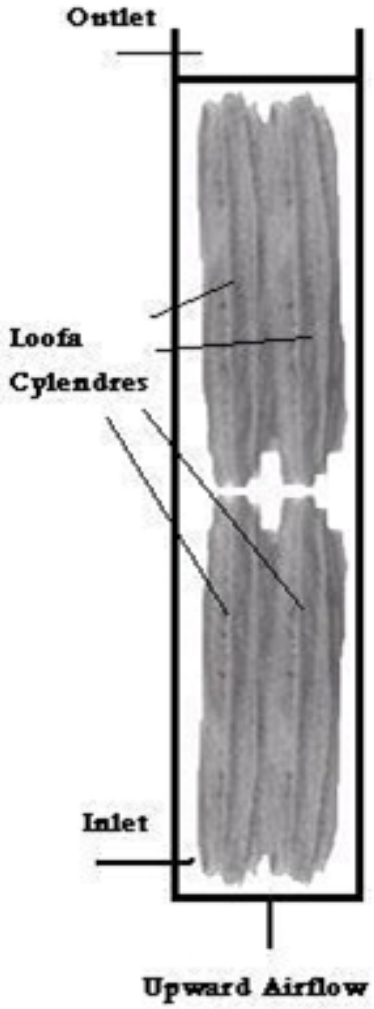

Figure 1. The schematic diagram of longitudinal section of ASFFR reactor.

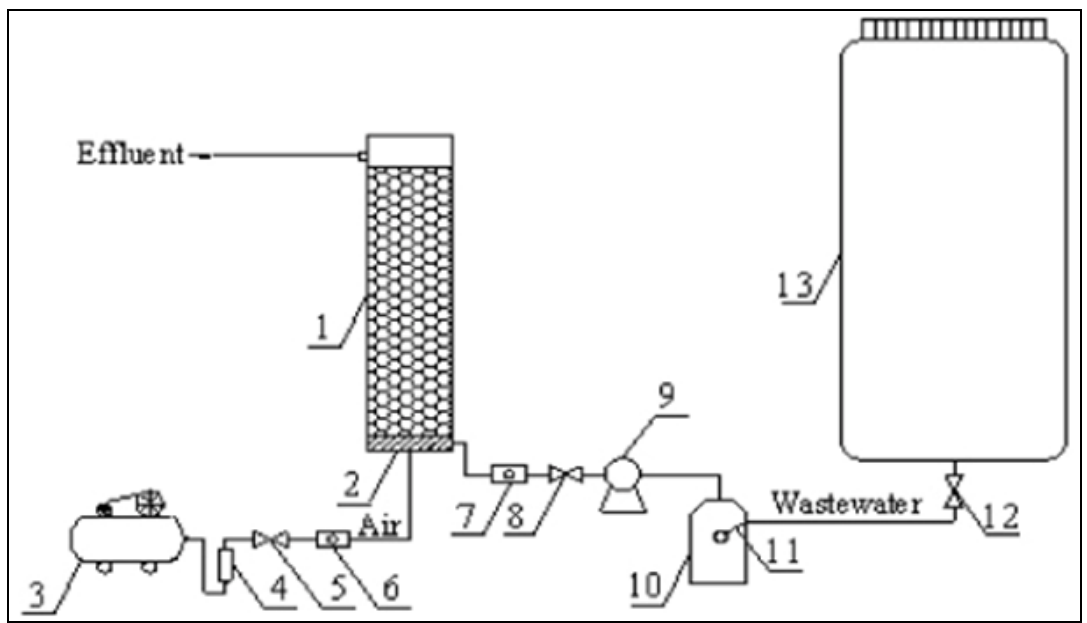

Figure 2. Schematic diagram of ASFFR and related equipment. (1) aerated submerged fixed-filmbioreactor, (2) round diffuser, (3) air compressor, (4) activated carbon column, (5, 8 and 12) cutoff valve, (6) air rotameter, (9) wastewater pump, (10) equalization tank, (11) floater, (13) reservoir. 


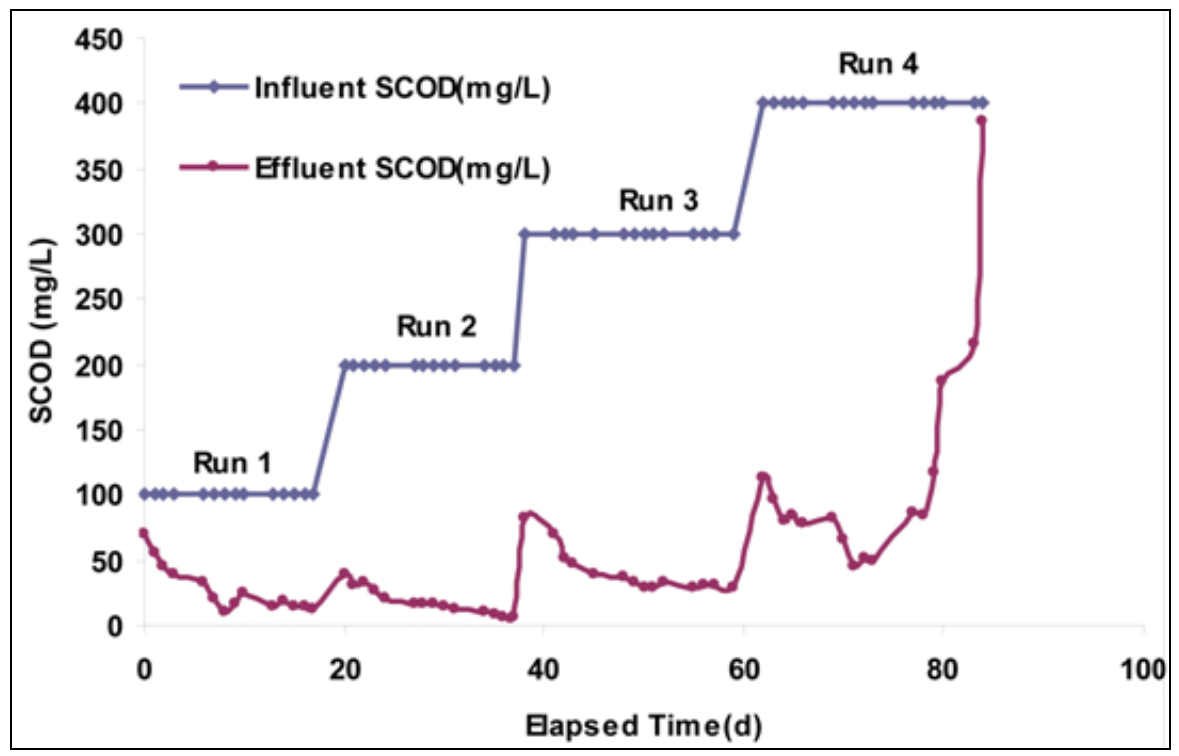

Figure 3. Variations of influent and effluent soluble COD versus time in all pilot runs. Run 1: influent $C O D=100 \mathrm{mg} \mathrm{L}^{-1}$; Run 2 : influent COD = $200 \mathrm{mg} \mathrm{L}^{-1}$; Run 3: influent COD $=300 \mathrm{mg} \mathrm{L}^{-1}$; Run 4: influent COD $=400 \mathrm{mg} \mathrm{L}^{-1}$.

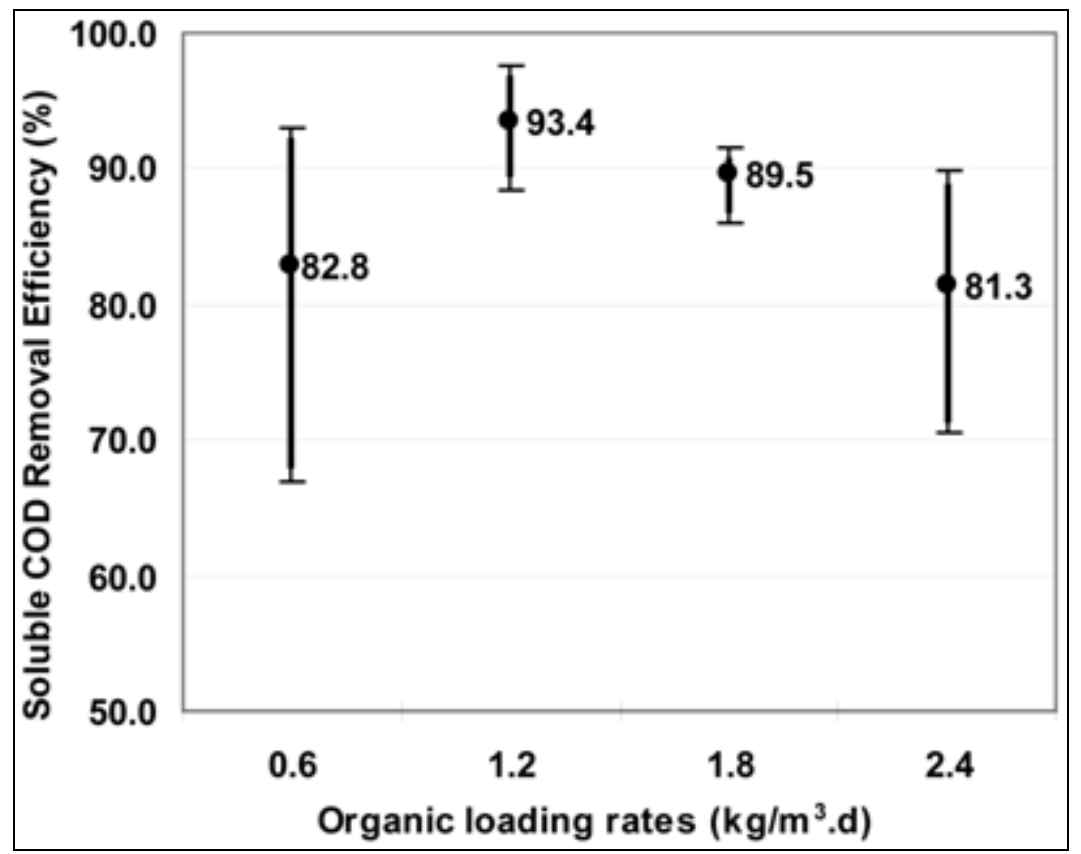

Figure 4. Effluent soluble COD removal efficiency versus organic loading rates. 


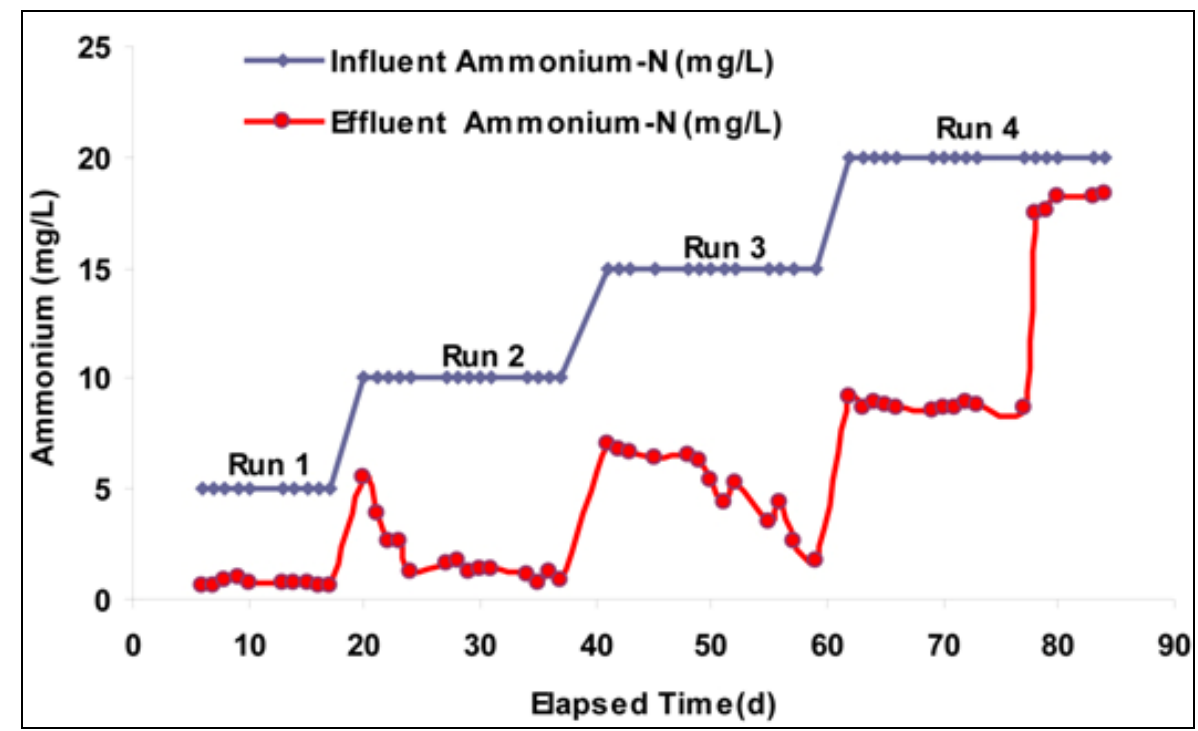

Figure 5. Variations of influent and effluent ammonium versus time in all pilot runs. Run 1: influent $C O D=100 \mathrm{mg} \mathrm{L^{-1 }}$ influent ammonium- $\mathrm{N}=5 \mathrm{mg} \mathrm{L}^{-1}$; Run 2: influent $C D=200 \mathrm{mg} \mathrm{L}^{-1}$ influent ammonium- $\mathrm{N}=10 \mathrm{mg} \mathrm{L}^{-1}$; Run 3: influent $C O D=300 \mathrm{mg} \mathrm{L}^{-1}$ influent ammonium- $=15 \mathrm{mg} \mathrm{L}^{-1}$; Run 4: influent $\mathrm{COD}=400 \mathrm{mg} \mathrm{L}^{-1}$ influent ammonium- $\mathrm{N}=20 \mathrm{mg} \mathrm{L}^{-1}$. 